\title{
FREUD AND PHILOSOPHY
}

\section{An Essay on Interpretation}

by Paul Ricoeur, Professor of Philosophy at the University of Paris Translated by Denis Savage

This book reveals Ricoeur the philosopher of language; Ricoeur the critic of Freud; and Ricoeur the theologian of religious symbol. The author is outstanding in all three roles, and the book that emerges is of rare profundity, enormous scope, and complete timeliness.

The first part of Freud and Philosophy, "Problematic", presents a profound and clear theory of signification, symbol, and interpretation. The second part, "A Reading of Freud", is required reading for anyone seriously interested in psychoanalysis. The third section includes a thoroughly audacious interpretation and criticism of Freud and a presentation of Ricoeur's own theory of symbolparticularly religious symbol-which places this study at the centre of contemporary debate over the sense of myth.

Terry Lectures 573 pages $135 s$

\section{YALE UNIVERSITY PRESS} 70\%Great Russell Street London WC1

\section{THE DEFINITION OF MORALITY}

\section{Edited by G. Wallace and A. D. M. Walker}

The papers brought together in this book are in response to much recent discussion among moral philosophers as to the definition of morality and moral issues-for example, what characteristics distinguish them from the law and legal issues or etiquette and matters of good taste?

Contributors: G. Wallace, A. D. M. Walker, C. A. Whiteley, Alasdair MacIntyre, W. K. Frankena, C. C. W. Taylor, Neil Cooper, P. F. Strawson, T. L. S. Sprigge, Philippa Foot, Kurt Baier, G. E. M. Anscombe, D. P. Gauthier. 


\section{The Philosophy of the Social Sciences}

\section{Alan Ryan}

Are the social sciences in principle different and more dubious undertakings than the natural sciences?

This book is an introduction to the major problems of the philosophy of social science. It covers the central sometimes controversial topics in the present debate, but demands no previous knowledge either of philosophy or the social sciences.

50s. Papermac 20s

\section{Modern Deductive Logic}

An Introduction to its Techniques and to its Significance.

\section{Robert John Ackermann}

A volume in the Modern Introduction to Philosophy series

This book is an introduction to modern techniques of deductive logic and a discussion of their scope and significance which can be readily understood without prior mathematical or logical instruction. An unusual feature is the wealth of exercises with partly programmed answers so that the book may be used for self instruction.

50s. Papermac 15s

\section{Kant: The Philosophy of Right}

\section{Jeffrie G. Murphy}

A volume in the Philosophers in Perspective series.

The book presents a critical exposition of Kant's political philosophy with particular emphasis on Kant's rather neglected theory of right. It provides the student with sufficient background in Kant's epistemology and ethics to understand his social and political philosophy.

30s. Papermac 10s 


\section{The Concept of Miracle}

\section{Richard Swinburne}

Most, if not all, religions claim that miracles have occurred. These who reject miracles do so for different reasons. This book analyses the meaning of the claim that a miracle occurred, and the evidence which could be brought or against such a claim.

13s

\section{Death and Immortality}

\section{Z. Phillips}

Is death the end? Are men immortal? This monograph treats these ageold questions in a way which is informative, very original and controversial. It will be of lively interest to all who study the philosophy of religion or reflect seriously about religious belief.

$13 \mathrm{~s}$

\section{Religion and Secularization}

\section{Vernon Pratt}

Do religious beliefs have any meaning in a secular age? The book explores what is meant by 'secularization', surveys theological reactions to it and investigates some of its wider implications. This monograph, like others of the series, combines a comprehensive critical review of what representative thinkers have said about its subject with $\mathrm{i}$ mportant and original contributions by the author himself.

13s

\section{MACMILLAN}




\section{MAN, \\ THE UNIVERSE and MIND}

\section{P. A. Moritz}

A new type of approach to problems of Perception, Object, World and Mind theory, utilising the procedures of Empirical Analysis .... a 20th century version of the British native Empiricist method.

102 pages

10s. $6 \mathrm{~d}$.

Supplementary to which is now available

\section{DIALECTICAL THINKING IN EMPIRICAL ANALYSIS}

by the same author

A detailed exposition of the above analytic procedure, including the consistency calculus, the principles of Truth Direction and of Insight-Level progressions.

80 pages.

3s. $6 \mathrm{~d}$.

Duplicated. Printed Card Cover.

Martigan Publications

\section{MEMORY TRAINING}

Are you the victim of "I forgot" or "I don't remember".

Time, money and success can be gained by the possessor of a good memory. $A$ bad memory brings about missed opportunities, lack of advancement and failure.

Our Psycho-tape No. ST $/ 9$ will develope your mental powers in such a way that you will remember lists of words, telephone numbers, names, facts and figures.

Send now for particulars of this and 20 other tapes on self-improvement. They include:-

Vita-Dynamics.

Public Speaking.

Mind Management.

Trance Deepening.

Confidence Course.

Publications :-

Sleep-learning: Its Theory and Technique.

Montal Powor through Sleep-suggestion.

Distributors of the Cassette battery/mains Sleep-o-matic Unit. Pillow speakors Time Clocks, and the new amazing whispering pillow.

Brochures from

EDUCATIONAL RECORDINGS LTD.

21 Bishops Close, London, E.17

\section{The PHILOSOPHICAL QUARTERLY}

Contents of Volume 20, No. 80, July 1970 SPECIAL REVIEW NUMBER ARTICLES

I The Mind-Brain Identity Hypothesis

II Transcendental Arguments C. H. Whiteley

\author{
$\boldsymbol{T}$ E. Wilkerson
}

III Strawson on Outer Objects Ross Harrison IV "Analysing" 'Know(s) that' Colin Radford $\checkmark$ Hume, Flew, and the Miraculous

DISCUSSIONS

R. C. Wallace

1 Mixed and False Pleasure in the

philebus: A Reply James C. Dybikowski II Qualities and Owners Douglas Odegard IIf The Existence of Mental Images

BIBLIOGRAPHY

Reynold Lawrie

Forty Years of Work on John Locke

A Bibliography

Roland Hall and

BOOX REVIEWS

LIST OF BOOKS RECEIVED

Edted by G. P. BCnderson with the assistance of Anthony Ralls, L. C. Holborow, and N. G. E. Harris and published for the scots N. G. E. Harris and published for the Scots
Phillosophical Club by the University of St. Andrews.

Price twonty-five hillings per annum (in U.S.A. $\$ 4.00$ ), post free, for order placed directly with the Treasurer (Mr. C. J. Bryant, Department of Moral Philosophy, The Univertity, St. Andrews. Scotland) or the Arsistant Trensurer (Professor Stanley Bates, Department of Philosophy, University of Chicamo, Chicsro, Illinois 60637, U.S.A.). For orders placed through booksellers or For orders placed through booksellers or (in U.8. \$5.00).
Advertisement Department for

\section{Philosophy}

T. G. SCOTT \& SON LIMITED

1 Clement's Inn, London WC2A 2ED

TEL: $01-2426264$

01-405 4743

Full detalis of rates and circulation oupplied on requeat. 


\section{Russell Remembered Rupert Crawshay-Williams}

Rupert Crawshay-Williams was a close friend and neighbour of Bertrand Russell during the last 25 years of his life. This close-up portrait attempts to show how Russell's genius manifested itself in everyday life, and includes a chapter which describes his relations with, and feelings about, current philosophy. Frontispiece 40/-

\section{Newman}

The Contemplation of Mind

\section{Thomas Vargish}

Mr Vargish examines Newman's philosophy of mind in detail, as first expressed in his Evangelical youth and as fully developed in his Oxford sermons and in the Grammar of Assent. He then uses this examination to interpret Newman's great statements on English society, on the aims of education, and on his own conversion. 45/-

\section{God and Rationality}

\section{Thomas F. Torrance}

This is a sequel to Professor Torrance's Theological Science (84/-), and to his Space, Time and Incarnation (25/-). In it he calls for a 'return to theological rationality', analyses the current 'Eclipse of God', and relates his position to the costly grace of God in Christ. 45/-

\section{First and Last Notebooks Simone Weil}

\section{Edited by Sir Richard Rees}

The publication of the notebooks of Simone Weil in English is now complete. Both her first and last notebooks were clearly written with future books in mind, and they provide an unselfconscious selfportrait of one of the most remarkable minds and characters of this century. 2 plates $60 /-$

\section{Rousseau: Religious Writings}

\section{Ronald Grimsley}

Professor Grimsley has brought together writings hitherto dispersed among the many volumes of Rousseau's work and correspondence. The letters are included with the didactic writings, and an introduction to each section situates it in Rousseau's production as a whole. 70/- 


\section{The Principles of Scientific Thinking}

\section{R. HARRÉ}

The first really comprehensive account of an alternative theory of science to positivism, this is potentially a most important contribution to the philosophy of science.

There are no other books which support this particular theory and it should stimulate much refreshing thought.

£4.50 (90s.)

\section{MACMILLAN}

\section{Back Issues of Journals} in

\section{THE HUMANITIES AND SCIENCES}

always required by

Wm. DAWSON \& SONS LTD.

Back Issues Department

Cannon House

Folkestone, Kent

England

Telephone: Folkestone 57421

Cables : Dawbooks Folkestone
Recent titles from

Steven M. Cahn

HARPER \& ROW

THE PHILOSOPHY OF RELIGION A collection of contemporary essays, presenting the central arguments and course of development since 1950.

Michael Gelvin

Paperback 46/.

A COMMENTARY ON

HEIDEGGAR'S 'BEING AND TIME'

Intended for those who wish to study

Heidegger in the original yet still desire a

detailed, explanatory commentary.

Martin Heidegger

Paperback 28/-

HEGEL'S CONCEPT OF

EXPERIENCE

(Edited by J. Glenn Gray)

Martin Heidegger

Cloth

$47 /-$

IDENTITY AND DIFFERENCE

(Edited by J. Glenn Gray)

Gerald J. Massey

Cloth

$$
47 /-
$$

UNDERSTANDING SYMBOLIC

LOGIC

A comprehensive, lucid introduction to standard logic, Church and Godel

Theorems, tense and modal logic.

Cloth

93/- 


\title{
Schiller and the Ideal of Freedom
}

\section{A Study of Schiller's Philosophical Works with Chapters on Kant}

\section{R. D. Miller}

In this study of Schiller's philosophy the ideal of freedom is shown to be central to his whole thought, relevant both to his moral philosophy and to his aesthetic theories, and illuminating his ideas on poetry as well as his views on the modern state. Sir Isaiah Berlin has contributed a foreword. Second edition 30\%.

\section{Early German Philosophy}

Kant and His Predecessors

\section{Lewis White Beck}

This is a comprehensive history of German philosophy from its medieval beginnings to near the end of the $18 \mathrm{th}$ century. Separate chapters are devoted to Nicholas of Cusa, Leibniz, Lessing and Kant. Frontispiece $£ 7 / 5 \%$ Harvard University Press

\section{Plato's Psychology}

\section{T. M. Robinson}

This book is the only definitive modern discussion of the nature and development of Plato's concept of Psyche. It explores and analyses those dialogues which are the most important sources for this subject, the Phaedo, Republic, Timaeus and Laws. 63/- University of

Toronto Press

\section{The Collected Papers of Clarence Irving Lewis}

\author{
Edited by John D. Goheen \\ and John L. Mothershead
}

f7/5/- Stanford University Press 


\section{PHILOSOPHICAL BOOKS}



Philosophical Books, edited by Professor J. Kemp, was started in 1960 with the object of assisting librarians and individuals in the choice of books in the field of philosophy. Reviews in the professional journals often appear some considerable time after the publication of the book, while reviews in the general weeklies are often inadequate in length and in quality for professional purposes. The aim of Philosophical Books is to provide reviews that are both reasonably prompt and of a high professional standard. Reviews are normally between 300 and 1,000 words in length, though they are occasionally longer. The journal appears three times a year, in January, May and October. Paper covered. 36 pp. Subscription 20s. (\$2.40) per year. Single copies $7 \mathrm{~s}$.

\section{LEICESTER UNIVERSITY PRESS}

2 University Road, Leicester LEI 7RB, England

\section{MIND}

A Quarterly Review of Psychology and Philosophy Edited by: Prof. GILBERT RYLE

\section{OCTOBER, 1970}

I. The Whole Number: G. FREGE.

II. Phenomenological Psychology: D. C. S. OOSTHUIZEN

III. Mind, Brain and Identity: STEWART CANDLISH

IV. Aristotle's Principle of Individuation: A. C. LLOYD

V. Distinguishing the Senses: J. W. ROXBEE COX

VI. The Expression of Emotion: O. H. GREEN

VII. Linguistic Nominalism: DAVID D. WELKER

VIII. Discussion Notes:

Resurrection Bodies and Resurrection Worlds: A. OLDING

Ockham on Mental: JOHN TRENTMAN

Two Remarks on Hempel's Logic of Confirmation: J. A. COFFA

On Thalberg's Condition for Cause: W. R. CARTER

Statements and Incorrigibility: SIDNEY D. JOHNSON

Mackenzie on Fact and Value: P. P. NICHOLSON

Recollecting and 'Recollecting': JOHN KING-FARLOW

Feeling Awed by God: VERNON PRATT

Mellor's Mistakes about Taylor's The Explanation of Behaviour: L. C. HOLBOROW

The Paradox of the Preface: A. R. LACEY

Why the " $S$ " in "Intension"?: MARY SPENCER

IX. Critical Notice:

D. C. Dennett: Content and Consciousness: J. J. C. SMART

X. New Books

XI. Notes

\section{Published for the MIND ASSOCIATION by BASL BLACKWELL, 49 Broad Street, Oxford}




\section{Models of Thinking}

\section{FRANK GEORGE}

In this study the more logical types of human thinking are analysed, such as the ability to abstract and the development of concepts. Professor George describes the features that have long been regarded as central to thinking by experimental and theoretical psychologists and places a greater emphasis on the part played by language in cognitive affairs.

Advances in Psychology Series, Vol. I. Cloth 35s Paper 21s

\section{Meaning in the Arts}

\section{LOUIS ARNAUD REID}

Explores in a new way the crucial problem of aesthetic meaning. The thesis of embodiment (rather than expression) as a key idea is worked and tested out in different arts and most of the seminal topics of aesthetics are lucidly discussed.

Muirhead Library of Philosophy

$70 s$

\section{The Subject of Consciousness}

C. O. EVANS

Attempts to account for the self from one's own case have led either to variants of the Pure Ego Theory or to variants of the Serial Theory. The author disputes this too easy dichotomy by presenting a third alternative. He develops a theory which is at once simple in conception and powerful in its ability to overcome the objections against the traditional theories. Muirhead Library of Philosophy

\section{Contemporary American Philosophy}

\section{Edited by J. E. SMITH}

\section{Second Series}

The aim of this book is to present a cross-section of philosophical thinking in America at present. No one type of philosophy, either with respect to method or viewpoint, has guided the editor in inviting contributors. Rather, an effort has been made to show how rich and varied a philosophical diet is available. Naturalism and Idealism, personalism and pragmatism, analysis and speculative philosophy are all represented, and the ideas of fourteen, junior as well as senior, philosophers are included. Muirhead Library of Philosophy

October $75 s$

\section{Ethics and Christianity}

\section{KEITH WARD}

This book explores the logic of Christian ethics in the light of contemporary moral philosophy. As it expounds a specific moral viewpoint which has been neglected in much recent discussion, it will be important to moral philosophers; it will also be of interest to theologians, as an outline of the basic framework of Christian ethics, offering a constructive discussion of revelation and authority.

Muirhead Library of Philosophy

\section{George Allen \& Unurin}




\title{
THEORY AND DECISION
}

An International Journal for Philosophy and Methodology of the Social Sciences

Editors:

Gerald Eberlein, Free University of Berlin, Berlin, Germany

Werner Kroeber-Riel, University of Saarland, Saarbrücken, Germany

Werner Leinfellner, University of Nebraska, Lincoln, U.S.A.

Alex C. Michalos, University of Pittsburgh, Pittsburgh, Pa., U.S.A.

\section{Board of Consulting Editors:}

Hans Albert, Klaus Baumgärtner, Karl Borch, Raymond Boudon, Gerhart Bruckmann, Rudolf Carnap, Noam Chomsky, C. West Churchman, James Coleman, Felix von Cube, Eberhard Fels, Herbert Feigl, Gerhard Frey, Gerhard Gäfgen, Peter Hammer, Jaakko Hintikka, Ulrich Klug, Paul F. Lazarsfeld, R. Duncan Luce, Rainer Mackensen, K. B. Madsen, Karl Menger, Oskar Morgenstern, Jean Piaget, Anatol Rapoport, Nicholas Rescher, Erwin K. Scheuch, Patrick Suppes, Thure von Uexküll.

THEORY AND DECISION concentrates on three major points of interest common to economics and the social and political sciences: (1) Application of modern methods and advances in philosophy of science and co-relevant formal sciences, (2) Analysis of formal structures, (3) Intensification of interdisciplinary communication.

The methods of philosophy of science, and especially the methods of the analysis of scientific languages and of their underlying logic, together with the analysis of the general and specific methods of social and political sciences and economics will be of decisive importance in future to the social and political sciences and to economics.

Theory AND Deciston is dedicated to the analysis and application of these methods. The aim is not to philosophize without intrinsic obligation, but to analyze concrete presuppositions, axiomatizations, and structures, and to criticize the methods and results of the above-mentioned sciences, for the purpose of increasing their efficiency and integration.

The common interest in philosophy of science and comparable formal structures of social and political sciences and economics consociates not only classical economics and social sciences, but also more recent areas of the humanities, as comparative behavioral science, ecology, modern pedagogy, cultural anthropology, modern linguistics, social psychiatry, etc.

THEORY AND DECISION will concentrate the discussion between those disciplines and promote the unification of the basic theoretical concepts.

Subscription price per volume of 4 issues Dfl. 65.- (US \$ 18.20)

Volume 1, No. 1 will appear 1970

One volume will be published yearly

\section{REIDEL PUBLISHING COMPANY}

\author{
DORDRECHT - HOLLAND
}

